\title{
Isolation Improvement between Closely Spaced Microstrip Loop Antennas using Metamaterial Structure
}

\author{
Saish Bhende \\ Undergraduate Student, \\ Electronics and \\ Telecommunication \\ Engineering Department, \\ Dwarkadas J. Sanghvi \\ College of Engineering, \\ Mumbai, India.
}

\author{
Sanket Shah \\ Undergraduate Student, \\ Electronics and \\ Telecommunication \\ Engineering Department, \\ Dwarkadas J. Sanghvi \\ College of Engineering, \\ Mumbai, India.
}

\author{
Sufyan Mukri \\ Undergraduate Student, \\ Electronics and \\ Telecommunication \\ Engineering Department, \\ Dwarkadas J. Sanghvi \\ College of Engineering \\ Mumbai, India.
}

\author{
Meet Vaidya \\ Undergraduate Student, \\ Electronics and \\ Telecommunication \\ Engineering Department, \\ Dwarkadas J. Sanghvi \\ College of Engineering \\ Mumbai, India.
}

\begin{abstract}
This paper presents a new method to improve isolation between two loop antennas with absorber cells exhibiting negative permittivity and permeability at the aimed frequency of $2.5 \mathrm{GHz}$ [1]. The observed isolation was around $-17 \mathrm{dBs}$ when separation between Microstrip antennas was $\lambda / 24$. The Separation of $\lambda / 24$ was $5.2 \mathrm{~mm}$ at $2.5 \mathrm{GHz}$ and it was insufficient to provide desired radiation pattern and impedance bandwidth. This paper aims at presenting a new technique of isolation between closely spaced antennas that are separated by a distance of $\lambda / 16$ at $2.5 \mathrm{GHZ}$. This technique uses (metamaterials) MTM unit cell that exhibits negative permittivity and permeability. Insertion of negative permeability structure between two loop controls mutual coupling between them by controlling amount wave propagation due to surface wave and near field radiations [2]. Since material offers negative permeability, amount of magnetic coupling was reduced. The MTM Unit Cell having plasma frequency same as loop antenna resonating frequency was designed on FR4 dielectric material. From simulated results negative permeability had been extracted. The MTM is constructed using SRR (split ring resonator) and CSRR (complimentary split ring resonator). The desired result of this technique is to obtain isolation of more than $-20 \mathrm{~dB}$ at 2.5 GHz. Placement of MTM cell improves the isolation almost by $-35 \mathrm{dBs}$. Remarkable improvement in $-10 \mathrm{~dB}$ impedance bandwidth had been observed at $2.5 \mathrm{GHz}$. Proposed technique improves the impedance bandwidth for loop antenna for same number of loops and also improves its radiation pattern for minimum physical separation between loop antennas.
\end{abstract}

Keywords

Loop antenna, MTM, SRR, CSRR

\section{INTRODUCTION}

In the recent years due to advancement in the technology there arises a need for high quality wireless services for the multiple antenna system. However due to the close placement of the antennas, the problem of mutual coupling arises. This in turn reduces the efficient performance of the same. Therefore there arises a need for strong isolation between closely operating antennas. A standard method of improving isolation is to reduce the power radiation from propagating antennas and to increase distance between radiating antennas. This paper concentrates on the use of Split Ring Resonator (SRR) and Complementary Split Ring Resonator (CSRR) MTM (Metamaterials) for isolation between two antennas.[3] The MTM are artificial structures that exhibit negative permittivity and permeability in a particular range of frequencies. At the desired frequency, direction of propagation is reversed. Since the two antennas are etched on the same ground plane suffer from electromagnetic interference and this will increase as physical separation between them decreases. When an array of SRR and CRSS MTM was placed at the center of the two closely spaced Microstrip antennas, almost $-35 \mathrm{~dB}$ improvements in isolation was observed. Enhancement in isolation results in improvement in operating bandwidth and radiation pattern.

\section{PROPOSED LOOP ANTENNA}

The geometry of the proposed loop antenna is shown in fig. 1 . It was fed by $50 \Omega$ coaxial connector and designed on a FR-4 substrate (relative permittivity $=4.4$, thickness $1.6 \mathrm{~mm}$ ) [4]. The proposed antenna consists of a small square loop and a SRR shaped loop. The proposed loop antenna occupies a space with the dimensions of $21 \mathrm{~mm}$ X $24 \mathrm{~mm}$ X $1.6 \mathrm{~mm}$. The total length of the inner loop was $57 \mathrm{~mm}$ long, about half wavelength of the central frequency in the $2.5 \mathrm{GHz}$ band.

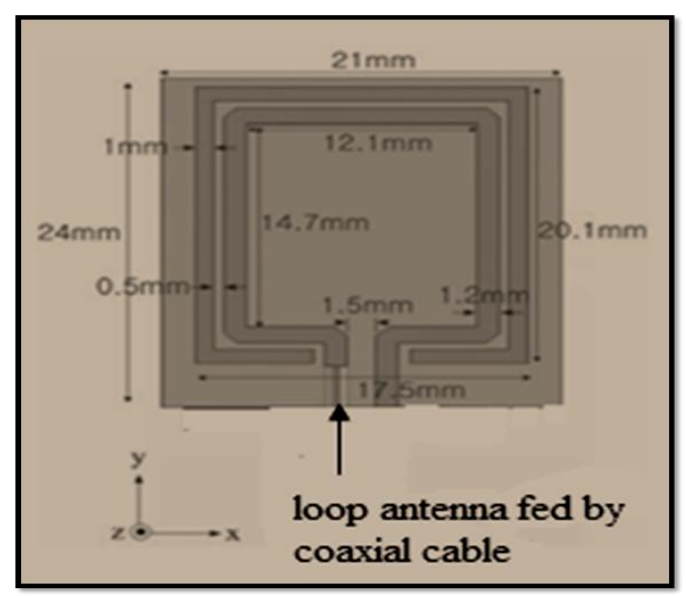

Fig 1: Loop Antenna fed by coaxial cable 
The MATLAB code was written for parameters extraction. Extraction of parameters from S-parameters was described in [5].

\section{TWO LOOP ANTENNAS SEPARATED WITHOUT ANY ISOLATION BETWEEN THEM}

Primarily, two loop antennas are used which separated by a distance of $\lambda / 16$. The dimensions of the loop antennas are as shown in the figure 6.1.The HFSS simulated version of the same is shown in the figure 2 also the final fabricated antenna is shown in the figure 3 .

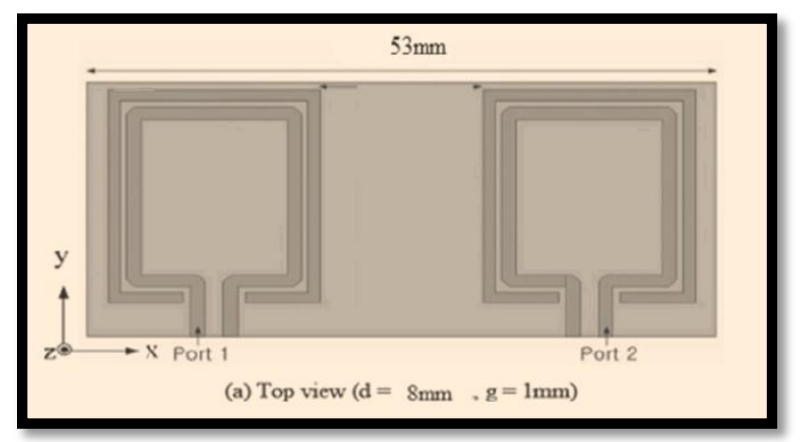

Fig 2: Design of Two Loop Antennas Separated Without Metamaterials

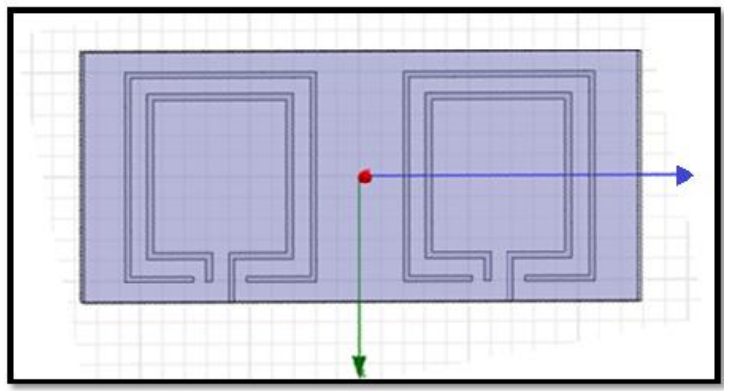

Fig 3: HFSS Model
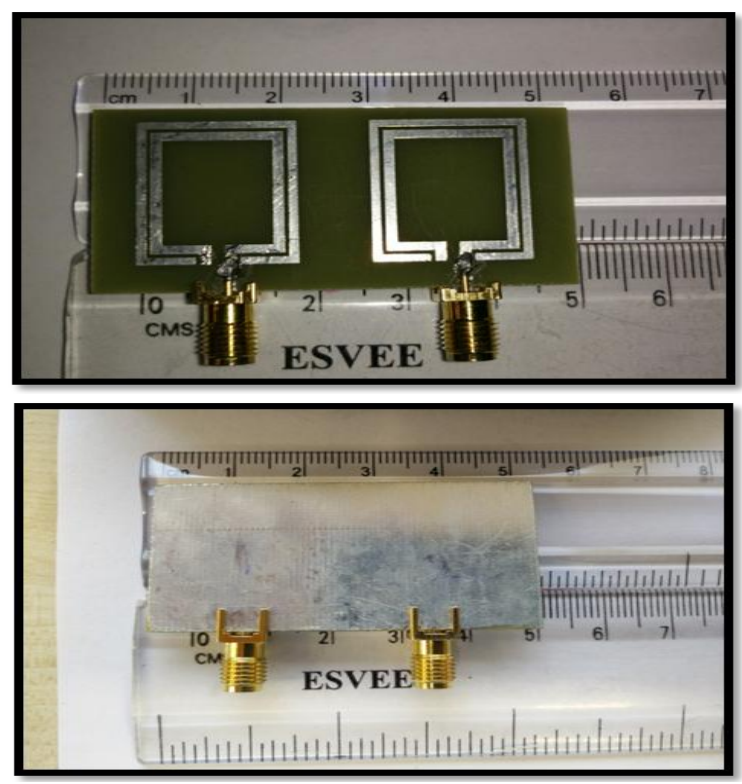

Fig 4: Fabricated Antennas
Figure 5 shows the graph of the $S$ parameter for different frequency and it can be seen that the $S_{11}$ is around $-11 \mathrm{~dB}$ for the frequency $2.5 \mathrm{GHz}$. The isolation parameter $\left(S_{12}\right)$ is around $-19 \mathrm{db}$ for closely spaced antenna that are not separated using metamaterial structures.[6] The S parameters are noted in the form of a table and then compared with the results of the fabricated one after testing.

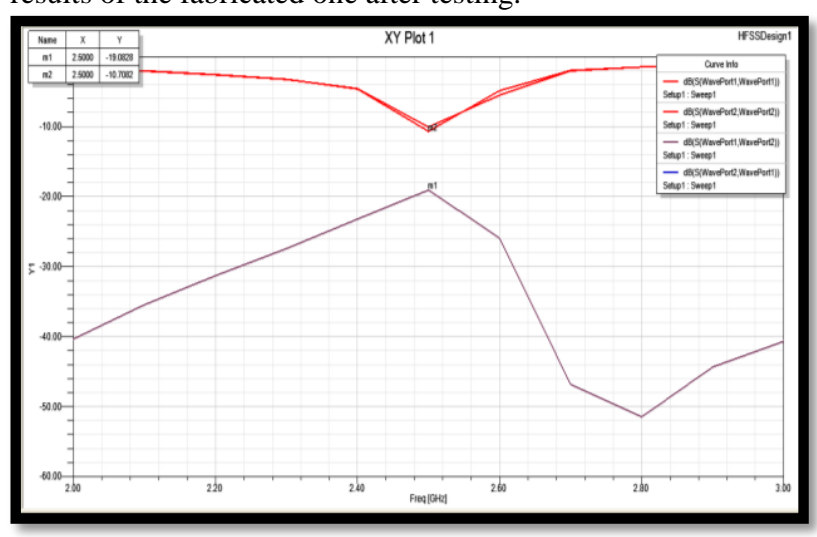

Fig 5: S - Parameter Graph

The graph shows that the $S_{11}$ for frequency $2.5 \mathrm{GHz}$ is -6.20 $\mathrm{dB}$ and the $\mathrm{S}_{12}$ for the same frequency is $-50.80 \mathrm{~dB}$.

Table 1: Comparison Of Simulated And Fabricated Loop Antennas Seperated By N/16 Without Srr And Ocsrr Cells

\begin{tabular}{|l|l|l|}
\hline $\begin{array}{l}\text { ANTENNA } \\
\text { PARAMETERS }\end{array}$ & $\begin{array}{l}\text { SIMULATED } \\
\text { RESULTS }\end{array}$ & $\begin{array}{l}\text { EXPERIMENTAL } \\
\text { RESULTS }\end{array}$ \\
\hline $\begin{array}{l}\text { Resonant frequency } \\
(\mathrm{GHz})\end{array}$ & 2.5 & 2.43 \\
\hline $\mathrm{S}_{11}(\mathrm{~dB})$ & -12.45 & -12.83 \\
\hline $\mathrm{S}_{22}(\mathrm{~dB})$ & -12.45 & -13.47 \\
\hline $\begin{array}{l}\text { Impedance } \\
\text { bandwidth }(\mathrm{MHz})\end{array}$ & 300 & 350 \\
\hline Isolation $\mathrm{S}_{21}(\mathrm{~dB})$ & -18.84 & -16.88 \\
\hline & -18.84 & -16.88 \\
\hline Isolation $\mathrm{S}_{12}(\mathrm{~dB})$ & & \\
\hline
\end{tabular}

From the table above, it is observed that isolation between two loop antennas without OCSRR and SRR at $2.5 \mathrm{GHz}$ is $-18.84 \mathrm{~dB}$ which is not sufficient

\section{TWO LOOP ANTENNAS SEPARATED WITH ISOLATION USING SRR AND OCSRR CELLS}

Meta-materials are used in order to improve the isolation between the loop antennas. The types of metamaterials proposed are SRR (split ring resonator) and OCSRR (open complimentary split ring resonator). [7]These structures exhibit negative permittivity and permeability at a certain frequency. We aim to achieve this at the frequency of $2.5 \mathrm{GHz}$. 


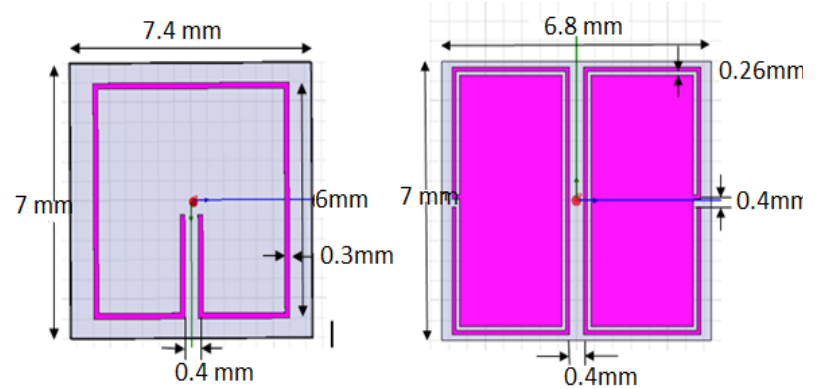

Fig 6: OCSRR and SRR Unit Cell Design
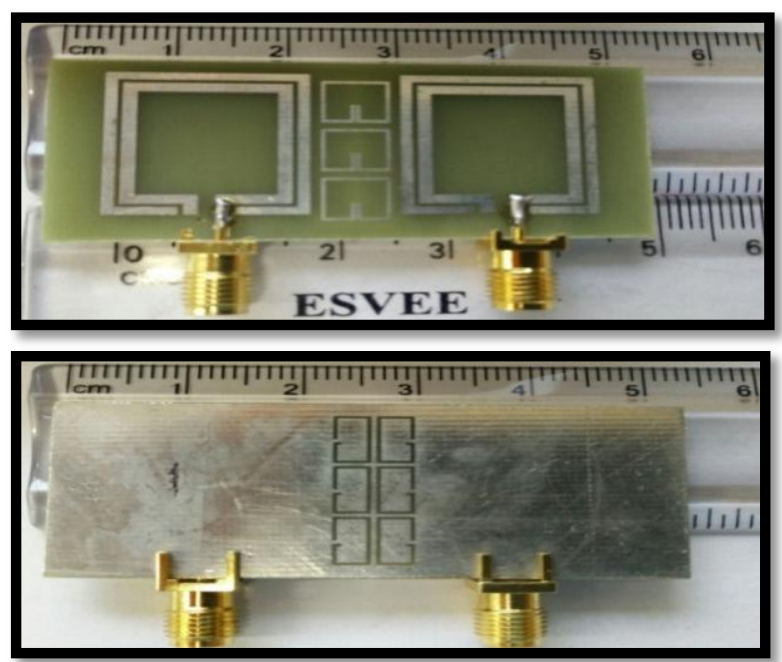

Fig 7: Fabricated prototype of the proposed loop antenna with OCSRR and SRRs.

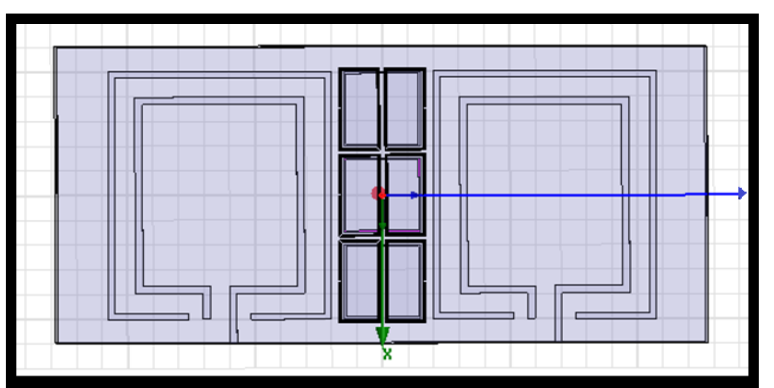

Fig 8: Front view HFSS model

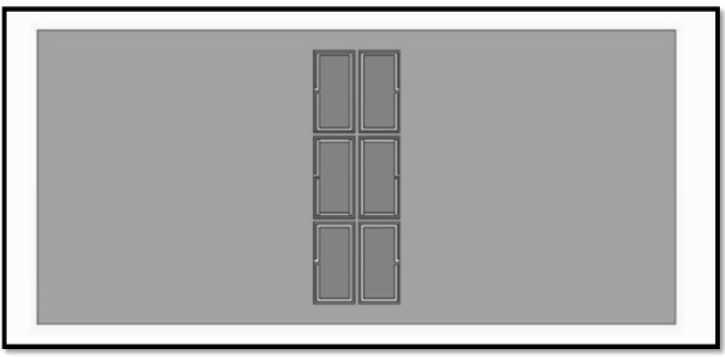

Fig 9: Bottom View HFSS model

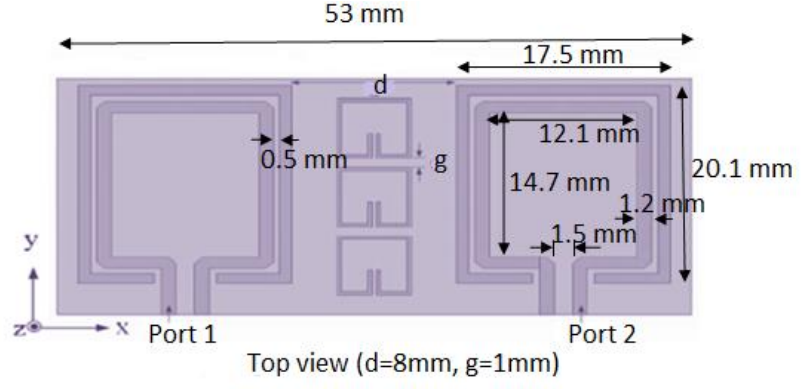

Fig 10: Diagram for Antennas Separated With SRR and OCSRR

When the inter-element spacing $\mathrm{d}$ was chosen as $8 \mathrm{~mm}$ during simulation, maximum isolation of $-62.07 \mathrm{~dB}$ between two antennas was obtained at $2.5 \mathrm{GHz}$. When three cells were placed between antennas, the port-to-port isolation $\mathrm{S}_{21}$ reduced more than $-42 \mathrm{~dB}$ at $2.5 \mathrm{GHz}$.

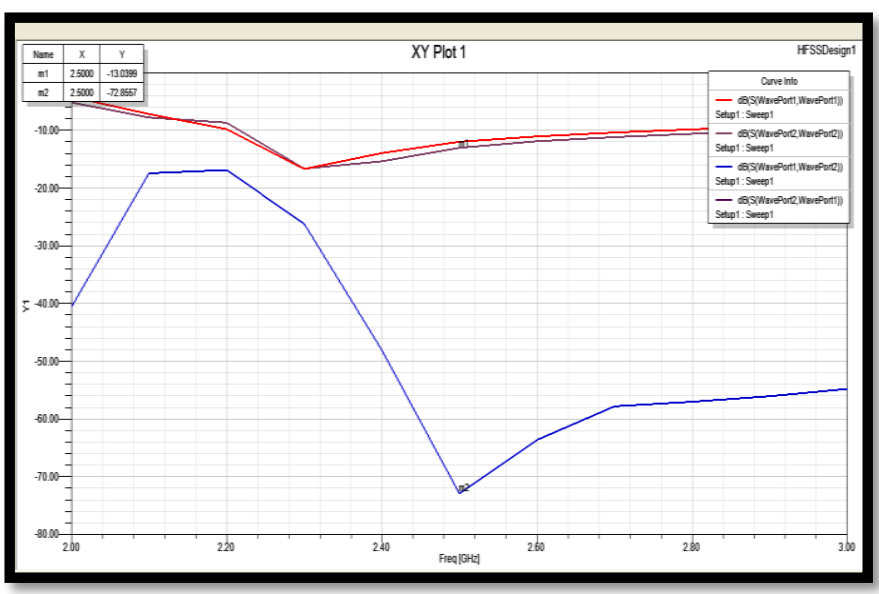

Fig 11: Simulated S-parameters of the proposed antenna with OCSRR and SRRs

Table 2: Comparison Of Simulated And Fabricated Loop Antennas Seperated By N/16 With Srr And Ocsrr Cells

\begin{tabular}{|l|c|c|}
\hline $\begin{array}{l}\text { ANTENNA } \\
\text { PARAMETE } \\
\text { R }\end{array}$ & $\begin{array}{c}\text { SIMULATED } \\
\text { RESULTS }\end{array}$ & $\begin{array}{c}\text { EXPERIMENT } \\
\text { RESULTS }\end{array}$ \\
\hline $\begin{array}{l}\text { Resonant } \\
\text { frequency } \\
(\mathrm{GHz})\end{array}$ & 2.5 & 2.43 \\
\hline $\mathrm{S}_{11}(\mathrm{~dB})$ & -16.21 & -15.75 \\
\hline $\mathrm{S}_{22}(\mathrm{~dB})$ & -13.03 & -17 \\
\hline $\begin{array}{l}\text { Impedance } \\
\text { bandwidth } \\
\text { (MHz) }\end{array}$ & 500 & 300 \\
\hline $\begin{array}{l}\text { Isolation } \mathrm{S}_{21} \\
\text { (dB) }\end{array}$ & -62.89 & -46.34 \\
\hline $\begin{array}{l}\text { Isolation } \mathrm{S}_{12} \\
\text { (dB) }\end{array}$ & -62.89 & -46.34 \\
\hline $\begin{array}{l}\text { Isolation } \\
\text { bandwidth over } \\
\text { resonant } \\
\text { frequency } \\
\text { (MHz) }\end{array}$ & 260 & 200 \\
\hline
\end{tabular}


From the table above, it is observed that isolation between two loop antennas with OCSRR and SRR at $2.5 \mathrm{GHz}$ is $62.89 \mathrm{~dB}$ for simulated results and $-46.34 \mathrm{~dB}$ for experimental results which shows increased isolation when compared to the antennas that are separated without isolation.

\section{COMPARISON OF RESULTS OF ANTENNAS SEPARATED WITH AND WITHOUT ISOLATION}

Table 3: Simulated Results Of The Proposed Antenna With And Without Ocsrr And Srr

\begin{tabular}{|c|c|c|}
\hline $\begin{array}{l}\text { ANTENNA } \\
\text { PARAMETER }\end{array}$ & $\begin{array}{c}\text { LOOP } \\
\text { ANTENNA } \\
\text { ELEMENTS } \\
\text { SEPARATED } \\
\text { BY } \\
\text { DISTANCE } \\
\lambda / 16 \\
\text { WITHOUT } \\
\text { OCSRR AND } \\
\text { SRR }\end{array}$ & $\begin{array}{l}\text { LOOP } \\
\text { ANTENNA } \\
\text { ELEMENTS } \\
\text { SEPARATED } \\
\text { BY } \\
\text { DISTANCE } \\
\lambda / 16 \text { WITH } \\
\text { OCSRR AND } \\
\text { SRR }\end{array}$ \\
\hline $\begin{array}{l}\text { Resonant } \\
\text { frequency } \\
(\mathrm{GHz})\end{array}$ & 2.5 & 2.5 \\
\hline $\mathrm{S}_{11}(\mathrm{~dB})$ & -12.45 & -16.21 \\
\hline $\mathrm{S}_{22}(\mathrm{~dB})$ & -12.45 & -13.03 \\
\hline $\begin{array}{l}\text { Impedance } \\
\text { bandwidth } \\
(\mathrm{MHz})\end{array}$ & 300 & 500 \\
\hline $\begin{array}{l}\text { Isolation } \mathrm{S}_{21} \\
\text { (dB) }\end{array}$ & -18.84 & -62.89 \\
\hline $\begin{array}{l}\text { Isolation } \mathrm{S}_{12} \\
\text { (dB) }\end{array}$ & -18.84 & -62.89 \\
\hline
\end{tabular}

Table 4: Experimental Results Of The Proposed Antenna With And Without Ocsrr And Srr

\begin{tabular}{|c|c|c|}
\hline $\begin{array}{c}\text { ANTENNA } \\
\text { PARAMETER }\end{array}$ & $\begin{array}{c}\text { LOOP } \\
\text { ANTENNA } \\
\text { ELEMENTS } \\
\text { SEPARATED } \\
\text { BY } \\
\text { DISTANCE } \\
\lambda / 16 \\
\text { WITHOUT } \\
\text { OCSRR AND } \\
\text { SRR }\end{array}$ & $\begin{array}{c}\text { LOOP } \\
\text { ANTENNA } \\
\text { ELEMENTS } \\
\text { SEPARATED } \\
\text { BY } \\
\text { DISTANCE } \\
\lambda / 16 \text { WITH } \\
\text { OCSRR AND } \\
\text { SRR }\end{array}$ \\
\hline $\begin{array}{c}\text { Resonant } \\
\text { frequency } \\
(\mathrm{GHz})\end{array}$ & 2.43 & 2.43 \\
\hline $\mathrm{S}_{11}(\mathrm{~dB})$ & -12.83 & -15.75 \\
\hline $\mathrm{S}_{22}(\mathrm{~dB})$ & -13.47 & -17 \\
\hline $\begin{array}{c}\text { Impedance } \\
\text { bandwidth } \\
(\mathrm{MHz})\end{array}$ & 350 & 300 \\
\hline $\begin{array}{l}\text { Isolation } S_{21} \\
(\mathrm{~dB})\end{array}$ & -16.88 & -46.34 \\
\hline $\begin{array}{l}\text { Isolation } S_{12} \\
\text { (dB) }\end{array}$ & $\begin{array}{l}-16.88 \\
\end{array}$ & -46.34 \\
\hline
\end{tabular}

\section{CONCLUSION}

This project gives insight into using metamaterial structures SRR (split ring resonator) and OCSRR (open complimentary split ring resonator) for isolation between two closely spaced antennas. The presented SRR and OCSRR exhibit negative permittivity and permeability at resonant frequency. This property is used for isolation between the loop antennas at $2.5 \mathrm{GHz}$. From the results, it is observed that with the placement of SRR and OCSRR the isolation is improved to a great extent. The achieved isolation is around $-50 \mathrm{~dB}$ for antennas separated by metamaterials over $-16 \mathrm{~dB}$ for antennas without metamaterials between them. Thus improvement in isolation at aimed frequency of $2.5 \mathrm{GHz}$ is achieved. Also there is improvement in the impedance bandwidth. It is also observed that the isolation remains in the desired range for a wide range of frequency. This improvement in the antenna isolation and impedance bandwidth is achieved without considerable changes in the antenna dimensions. The future scope of this technique is immense given the fact that very less changes are required in the original dimensions of the antenna. Good improvement in isolation over the desired impedance band allow close placement for antennas which further reduces the antenna dimensions. Errors between measured and simulated results were within tolerable engineering limits.

\section{ACKNOWLEDGMENTS}

This project was carried out under the guidance of Professor Anuja Odhekar at Dwarkadas J. Sanghvi College of Engineering in Mumbai. 


\section{REFERENCES}

[1] N. I. Landy, S. Sajuyigbe, J. J. Mock, D. R. Smith, and W. J. Padilla, "Perfect metamaterial absorber," Phys. Rev. Lett., vol. 100, pp. 274021-4, May 2008.

[2] V. G. Veselago, Soviet Physics Uspekhi, Volume 10, Number 4 January-February 1968."The Electrodynamics Of Substances With Simultaneously Negative values Of E And $\mu$ " P. N. Lebedev Physics Institute, Academy Of Sciences, U.S.S.R. Usp. Fiz. Nauk 92, 517-526 (July, 1964).

[3] F. Martín, F. Falcone, J. Bonache, R. Marqués and M . Sorolla, "Split ring resonator based left handed coplanar waveguide", Appl. Phys. Lett., vol.83, pp. 4652-4654, December 2003.

[4] H.S.Lee, H.M.Lee, "Isolation Improvement between Loop Antennas with Absorber Cells", 978-1-4244-95610/11, IEEE 2011.
[5] D. R. Smith, D.C.Vier, ThKoschny, C.M.Soukoulis, Phys. Rev E 71, 036617,2005.

[6] Han, X., H. Hafdallah-Ouslimani, T. Zhang, and A. C. Priou, "CSRRs for efficient reduction of the electromagnetic interferences and mutual coupling in microstrip circuits," Progress In Electromagnetics Research B, Vol. 42, 291-309, 2012.

[7] B. D. Braaten, "A Novel Compact UHF RFID Tag Antenna Designed with Series Connected Open Complementary Split Ring Resonator (OCSRR) Particles," Accepted for publication in the IEEE Transactions on Antennas and Propagation. 